\title{
USAGE ANALYSIS AND EVALUATION OF SLAB TRACK CONSTRUCTIONS
}

\section{INESA GAILIENE' ${ }^{*}$, VAIDAS RAMŪNAS ${ }^{2}$ \\ ${ }^{1,2}$ Dept of Roads, Vilnius Gediminas Technical University, Vilnius, Lithuania}

Received 09 June 2017; accepted 19 May 2019

\begin{abstract}
Slab track is one of the technical possibilities to achieve the following goals: increase the conductivity of a railway, increase the highest permitted train speed, reduce the cost of railway maintenance, and increase the railway lifetime. However, the abundance of slab road constructions that occurred during the development stages presents a challenge to railway operators, designers and researchers, about the selection of a right slab track and establishing requirements to it. The present article analyses the ballastless track constructions that are used in the European Union and other world countries. The market is analysed, and a comparative evaluation of the ballastless track construction is carried out, based on the quality and price, by rating and providing the evaluation of usability and recommendations.
\end{abstract}

Keywords: ballasted track, ballastless track, Life Cycle Cost (LCC), maintenance, railway construction, Strengths, Weaknesses, Opportunities and Threats (SWOT) analysis.

\footnotetext{
* Corresponding author. E-mail: inesa.gailiene@vgtu.lt

Inesa GAILIENĖ (ORCID ID 0000-0002-4145-7352)

Vaidas RAMŪNAS (ORCID ID 0000-0003-2472-6677) 


\section{Introduction}

The ballastless track construction is extraordinary in the way that it does not have the traditional elements of the top railway construction, such as ballast, sleepers, in some cases couplings (when a continuous track attachment is applied). These constructions are used in straight lines, curves and the railway lines of one or multiple tracks with a various track width. Based on global practice, the range of using ballastless track constructions is extensive: it is applicable on bridges and viaducts, tunnels and railways on roadbeds, high-speed and simple railway lines, stations, level crossings, switches.

The classification of ballastless track constructions is provided in Table 1. The table provides the examples of slab tracks (not all existing constructions), based on the classification. In most academic sources and methodological tools, the classification is the same or different in a very slight manner (Ižvolt \& Šmalo, 2014; Marx \& Mosmann, 2013; Michas, 2012).

In some classifications, ballastless track constructions are illustrated with examples on which accessible sources contain little information or almost little information. There is a lack of studies or observations on their performance, advantages, disadvantages. Often specific constructions are mentioned only when classifying all slab track constructions. However, there are no or very little data on their development and use (constructions assigned to groups 2, 4 and 6 in Table 1).

Table 1. Classification of slab track constructions

\begin{tabular}{|c|c|c|c|c|c|c|}
\hline & 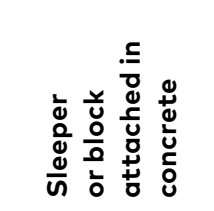 & 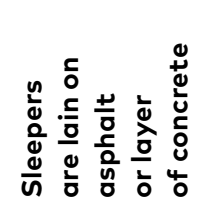 & 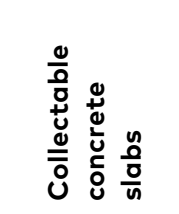 & 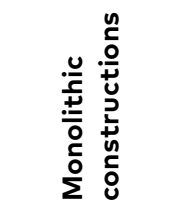 & 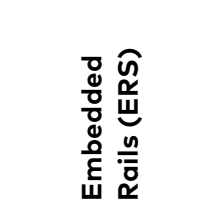 & 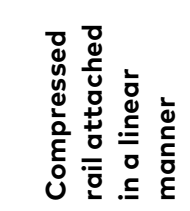 \\
\hline & Group 1 & Group 2 & Group 3 & Group 4 & Group 5 & Group 6 \\
\hline 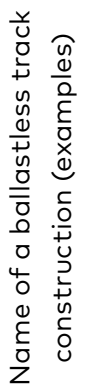 & $\begin{array}{l}\text { RHEDA; } \\
\text { RHEDA2OOO; } \\
\text { ZÜBLIN; } \\
\text { STEDEF; } \\
\text { SONNEVILLE- } \\
\text { LVT; } \\
\text { HEITKAMP; } \\
\text { SBV; } \\
\text { WALO }\end{array}$ & $\begin{array}{l}\text { ATD; } \\
\text { BTD; } \\
\text { SATO FFYS; } \\
\text { GETRAC; } \\
\text { WALTER }\end{array}$ & $\begin{array}{l}\text { JSLAB; } \\
\text { BÖGL; } \\
\text { ÖBB-PORR } \\
\text { IPA }\end{array}$ & $\begin{array}{l}\text { FFC; } \\
\text { HOCHTIEF; } \\
\text { BES; } \\
\text { PACT }\end{array}$ & $\begin{array}{l}\text { DECKTRACK; } \\
\text { INFUNDO- } \\
\text { EDILON; } \\
\text { BBERS }\end{array}$ & $\begin{array}{l}\text { COCON } \\
\text { TRACK; } \\
\text { ERL; } \\
\text { SAARGUMI }\end{array}$ \\
\hline
\end{tabular}


Slab track constructions also are divided by their place of use. That of Slab Track way, all constructions are classified as used on roadbeds, in tunnels, on bridges and viaducts. However, upon improving the existing constructions or designing the new ones, manufacturers aim at offering the constructions that are more universal with a use range as wide as possible; therefore, such classification is pointless.

One of the drawbacks of a slab track is the wide range of manufacturers and constructions. Hence, it is complicated to choose the best slab track. Some of the best-known used slab track constructions are as follows (Esveld, 1999; Ižvolt \& Šmalo, 2014): Rheda, Züblin, FF Bög and other options (Germany); Stedef (France), Sonneville Low Vibration (LVT) (Switzerland); Edilon Block Track (the Netherlands); Shinkansen (JSLAB) (Japan, South Korea); ÖBB-Porr (Austria).

\section{The practice of using slab track constructions in various countries}

Since the middle of the XX century in certain countries of the world, scientists and manufacturers studied and developed the usability of slab tracks. The main reason for this was the increase of axis load to the track and train speeds. It became harder for the traditional ballasted track construction to comply with the increasing requirements. Since then, the most important and complicated issues have been the time and place of using a slab track (Michas, 2012; Pichler \& Fenske, 2013). Another challenge that occurred together with the development and design of slab track constructions is the choice of a slab track construction, about the experience, obtained, local conditions and Life Cycle Cost (LCC).

The first ballastless track construction was designed a long time ago, around the beginning of the XX century. Significant development and usage of these constructions began in the 1970s. After 40 years of usage, the obtained information on the general performance is enough to begin at least a significant study and discussion on what requirements comply with these constructions.

The slab track constructions are studied, tested or used in many countries. In some countries, entire long sections are designed with the ballastless track constructions (has been the case for decades in some countries), such as China, Japan, South Korea, India, USA and Canada, the Netherlands, Italy, The United Kingdom, Germany, Austria, France, and Switzerland. Other countries only bring out the discussions on the usability, range, risks, of such constructions. Such countries include Sweden, Slovakia and Russia. 
The development analysis of slab track constructions is interesting when the analyses of various countries where slab track constructions are most widely used and studied are compared. The experience of the following countries was chosen for a more detailed analysis and observations: Japan, Holland, Germany, Austria, and France.

\subsection{Japan}

In 1965 the Japanese National Railway (JNR) that used the Japanese railways (as was the case from 1949 to 1987) began developing "new railway structures" (Yokoyama, 2010). In 1971 a committee was established that explicitly researched a ballastless track. Such attention to the ballastless track constructions, their study and usage make Japan a particular country in the history of a slab track development because this country was extraordinary in the way that it made a considerable effort and invested in the research of slab track constructions. The situation occurred because, before it, the Japanese engineers chose a ballasted track for their first line of high-speed railways Tokaido Shinkansen. However, soon it was necessary to limit the speed on the line to $210 \mathrm{~km} / \mathrm{h}$, there was an increase in repair works to fix the track in the plan and longitudinal profile. It was caused by the subsidence of a roadbed. Hence, on bridges and in tunnels, a ballastless track was begun to use. That way a ballastless track occurred in the Japanese line of highspeed railways Shinkansen. Even though initially the initiated and lain ballastless track was mounted on bridges and in tunnels, in the middle of 1970s it also lay on a roadbed.

The reinforced concrete roadbed system (RCRS) used in Japan is tested and monitored since the early 1990s, and in 1997 a permission was given to use a trial section. The Japanese estimated that the RCRS construction is approximately $18-24 \%$ more expensive than a ballastless track. It was expected that, due to the lower maintenance costs, this construction would recoup. It was also expected to save up to $30 \%$ on labour costs that are needed for the maintenance of slab tracks (Tayabji, 2000). The drawbacks that occurred during the usage of this construction are as follows: cement and asphalt mortar was infringed and the alkaline corrosion caused cracks in plates (Alkali-Silica Reaction (ASR) in the concrete mixture, this corrosion may even cause crumbling of certain constructions. Therefore, finding appropriate measures to decrease it and producing concrete resistant to the alkaline corrosion is an important task), plate deformations in tunnels occurred. Regardless of these flaws, the maintenance of slab tracks was significantly lower (from 0.18 to 0.33 , compared to the ballasted track), construction costs approximately 1.4 times more, and the recouping, depending on the tonnage, reached 8-12 years. 
The example of the Japanese induced the studies of usability of a slab of Slab Track track in Japan and Europe (Dieleman, Fumey, Robinet, Ramondec, \& Martin, 2008). The conception of study idea and design in Japan was as follows (Fröidh, 2014; Tayabji, 2000; Yokoyama, 2010):

- the construction price may be higher no more than two times the price of the ballasted track ;

- resilience and horizontal and vertical strength must be stronger than that of the ballasted track;

- the efficiency of construction works must be at least $200 \mathrm{~m}$ a day;

- road bumping (infringements), due to the worsening of roadbed condition, must not exceed tolerable limits $( \pm 50 \mathrm{~mm}$ in a vertical plate (longitudinal profile), $\pm 10 \mathrm{~mm}$ in a horizontal plate).

\subsection{Holland}

Most of the studies in Holland are carried out on the track constructions, in which the railway is mounted on the plate of a slab track (embedded system). This construction is different from other ballastless track constructions because the railway is mounted into the elastomeric layer (elastomeric layer (beam) is a set of chemical beams that are exclusively resilient; they are used for products requiring high resilience). Several innovative constructions were developed in the Netherlands: Embedded Rail System (ERS) and Edilon, DeckTrack.

The ERS construction has been used in the Netherlands since 1970. At first, it was used on bridges and in level crossings. Later, a 3-kilometre-length section lay on a roadbed in the south of the country. The construction consists of armoured concrete plates that are lain on the base stabilised with concrete, which is mounted on a sand layer. It was considered to use the ERS construction in the high-speed railway line HSLZuid that stretches from Amsterdam to the Belgian border (Tayabji, 2000). However, there was still a construction Rheda 2000 chosen in this section.

As already mentioned, the Edilon construction project was implemented in the Netherlands on concrete bridges (1976-2005) and metal bridges (1994-2004). The speed on these bridges is $140 \mathrm{~km} / \mathrm{h}$, and the axial load is $225 \mathrm{kN}$. This construction was also used in Spain in a tunnel and high-speed railway line in Madrid (between Chamartin and Atocha railway stations). This construction is used in Sweden, Germany, France, and the United Kingdom and most widely used on bridges and in tunnels.

The conception of an injection rail was developed in a newlydesigned BB ERS construction when a transverse profile was changed to a rectangle one (Esveld, 1999; Gautier, 2015). This construction was designed in 2000 and named BB ERS (Balfor Beatty embedded rail system). It firstly lay in Spain in 2002. 


\subsection{Germany}

Germany is one of the first countries that sought to find optimal slab track constructions. The first tests of a slab track construction there were carried out in 1959. The solution of a slab track was tested in a trial section of a research department of UIC that was constructed in the UK in 1967 for this particular purpose. The first ballastless track was built in 1972 in the railway station of the city of Rheda, Germany (Profillidis, 2016). The Rheda construction was designed in 1972 as a continuous slab, i.e. it was mounted on the road. As it was already mentioned, the first time it was used in 1972 in a section where the trains moved at the speed of $160 \mathrm{~km} / \mathrm{h}$ and the permitted load was $225 \mathrm{kN}$. Later, in 1989, it was used in the line where the train speed reached up to $250 \mathrm{~km} / \mathrm{h}$, and the axis load was $225 \mathrm{kN}$. In 2002 the Rheda construction in Germany was used in line with the train speed up to $300 \mathrm{~km} / \mathrm{h}$. The construction was developed over time, and it fostered the occurrence of Rheda 2000 (Gautier, 2015). This construction was mostly used in the lines of high-speed railways. High-speed train lines were constructed in Germany (Nürnberg-Ingolstadt in 2006) $-300 \mathrm{~km} / \mathrm{h}$ and axis load of $225 \mathrm{kN}$ ), the Netherlands (HSL-Zuid in 2006), Taiwan, Korea. In 1996 DB (German Railways) started using a trial section of a slab track that consisted of seven different slab track constructions (Esveld, 1999). The total length of the trial section is $330 \mathrm{~km}$. Germany, as Japan and Austria, has a wellknown construction of collectable plates designed. It is a Bögl construction that was mounted in the line Nürnberg-Ingolstadt in 2006. It was also used in the Chinese railways. A ballastless track becomes very important in the line of high-speed trains because its usability has been significantly improved lately. What is more, its performance complies with the high requirements established for a railway in the lines of high-speed trains (Mörscher, 1999). A railway line significant to the history of slab track development is the line Köln-Rhine-Main $(204 \mathrm{~km})$ that is all built using the slab track construction. It was found in Germany that it is efficient to use a ballastless track when its mounting cost no more than 1.4 times the cost of mounting a ballasted track (Bilow \& Randich, 2000). There is around $860 \mathrm{~km}$ of a ballasted track in the railway line of Germany. It adds to around $1.5 \%$ of the total German railway network. What is more, there are around 100 Switches lain.

\subsection{France}

Twenty-five years after the beginning to operate high-speed train lines on a ballasted track in France, it was decided to try using a ballastless track construction for a high-speed railway line European 

2007 , and a section of $300 \mathrm{~km}$ of the road was operated, and it is planned. The first stage of construction of this line was finished in 2007, and a section of $300 \mathrm{~km}$ of the road was operated (Dieleman, Fumey, Robinet, Ramondec, \& Martin, 2008).

The French engineers, already upon carrying out the first usability studies of TGV line, predicted that the dynamic forces caused by the traffic of high-speed trains negatively affect the geometric parameters both in the plate and the longitudinal profile. Hence, it was already then that they warned about the inevitable necessity of plenty of maintenance and repair works in the slab track of the high-speed lines to fix the track geometry and go together with a number of traffic breaks and speed limits. Just at around the same time in Japanese railways a railway construction with a ballast was assigned to the first high-speed line. After a while, the French realised they were right because soon the speed in the line was limited to $210 \mathrm{~km} / \mathrm{h}$, the need of track repairs rose rapidly because of the subsidence of both the roadbed and the ballast. So, the studies of usage of a ballastless track in Europe and France were induced.

The slab track has been used in France since 1960. Several constructions were chosen, but the most widely used ones are Monaco and Stedef. The operation of Monaco did not prove to be efficient, and its usage was terminated due to a price that was too high. Then the Stedef construction was chosen. This construction was designed by a French railway engineer Roger Sonneville. He later established two private companies that developed two constructions - Stedef and Sonneville. These constructions are different in the following way: Stedef construction consists of two-block sleepers, and in the Sonneville construction, two separate blocks are used. Stedef construction is used in Switzerland, Austria and Spain. In France, it is still used in tunnels because of exceptionally good resistance to vibration.

The Stedef construction has lain in a section of almost $2 \mathrm{~km}$ in the highspeed railway line TGV East. A lot of studies and estimations are carried out in the trial section, and they still go on. However, a few conclusions have already been drawn: it was found that, while using the Stedef construction, a relatively low construction is enough to ensure traffic of high-speed trains. Stresses in such construction are not lower than the ones in the ballasted track, even when a standard concrete is used.

\subsection{Austria}

A slab track was first used in the federal railways of Austria (German: Österreichische Bundesbahnen, ÖBB) in 1980. As the intensity of transportation and the permitted train speed increased, 
it was proven that, at least in tunnels, the ballastless track has key advantages over a ballasted track. Therefore, in tunnels in Austria that are longer than 500 meters, a slab track railway is installed (Pichler \& Fenske, 2013).

A few slab track constructions were tested in the ÖBB railway line from 1982 to 1995. They were divided into two groups: that of an integral construction (compact) and the construction of collectable plates. After a number of tests, it was discovered that the ÖBB-Porr construction of collectable plates is most usable in the Austrian railway lines. The ÖBB-Porr construction was mounted in all slab track sections in 1995 (it is used in tunnels, on roadbeds, in switches, high-speed train lines (since 2010) - in total around $170 \mathrm{~km}$ ). This construction almost does not require any maintenance works, except for such regular tasks as track polishing.

Much attention, while developing slab track construction, was dedicated to designing a mass-spring system. When these systems are used, noise and vibration emissions are much less than in the ballasted track. It is especially important in highly populated territories of Austria. Such noise and vibration mitigation systems have been designed and used since 1996.

The ÖBB-Porr construction designed in Austria is successfully applied in German railways (DB). In Germany, this structure is used not only in tunnels or on bridges, but also roadbeds and high-speed railways. Since 2001 this construction has been used in the main railway station in Berlin. From 2001 to 2013 in Germany, the ÖBB-Porr construction was mounted and operated in almost $300 \mathrm{~km}$ of railways.

\section{Comparative assessment of slab track constructions}

It is necessary to establish the assessment criteria that are used for the comparison to compare the slab track constructions concerning their quality and price. When the constructions that sometimes are fundamentally different from one another are compared, it is essential to establish the general (equally understandable and applicable) technical, performance and economic indicators that allow comparing and assessing the slab track constructions. The following indicators are:

- construction longevity;

- flexural strength;

- height of construction;

- level of noise and vibration; 
- areas and experience of applicability (the length of construction used);

- permitted train speed;

- maintenance costs and necessity;

- mounting price and time;

- permitted load and other parameters.

The choice of assessment criteria is aggravated because in different countries slab track constructions are tested, studied and assessed under different conditions, using different methodologies and in pursuance of different goals. Hence, not always is it possible to compare data; often, it is unreliable and even irrational and incorrect. The complicated situation is also caused because it is difficult to obtain data on the user experience of a slab track from the companies that operate them because they do not systematise nor generalise them. The manufacturers of ballastless track constructions never tend to indicate flaws and risks of their manufactured constructions upon their installation, maintenance and repair. Therefore, most often, research reports or academic articles provide generalised advantages and disadvantages of ballastless tracks.

Upon improving their constructions, all manufacturers of a slab track give a particular focus to the elimination of weak points, e.g. mitigation of noise and vibration. Many various technical solutions used in mitigating the vibration and noise in slab track constructions are provided. However, it is impossible to test how they perform in specific places under certain operating conditions. Due to the mentioned reasons, in many countries that seek to legalise the use of slab track constructions and selecting the construction that best fulfils all requirements, trial sections are installed. In separate parts of these sections, different slab track constructions lie. In case research is carried out during operation, the defects are identified and recorded, as well as necessary maintenance and repair work. This method is used to assess and compare the constructions, manufacturers and make decisions that are both technically and economically reasonable.

Comparing prices of slab tracks is also a complicated matter because they are compared correctly only if the prices of different slab track constructions are estimated for the same object. Therefore, the generalised comparison of different constructions is uninformative nor reliable concerning quality, and it cannot be treated as an essential factor when choosing a ballastless track.

Since any construction has advantages and disadvantages, it is extremely important to properly identify them and, having the necessities in mind, select a proper slab track construction. 
Since there are a lot of slab track constructions and manufacturers, it is firstly important to establish the extent of comparison, in consideration of the following:

- the classification of ballastless track constructions (Table 1);

- country of origin;

- length of railway in which a specific construction is used.

The country of origin and the length of railway in which a specific construction is used are provided in Table 2 and Figure 1. It is difficult to define an exact length of the railway in which a specific construction is used because numbers vary, especially in the constructions that are widely used in laying new lines or reconstructing the existing ones.

After analysing the classification and spread of various slab track constructions, it is necessary to highlight the constructions that are compared in this subsection. The main presumptions of choice are as follows:

- the constructions are widely used (over $200 \mathrm{~km}$ of railway lines) in some countries (Table 2);

- wide range of use of the construction: on bridges, in tunnels, on roadbeds;

- constructions manufactured and used in the member countries of the European Union because any other constructions from other continents could not compete with other constructions manufactured and used in Europe concerning price (including permissions, certificated, conformity assessments and risk reports that should be written);

Table 2. Use of slab track constructions

\begin{tabular}{llc}
\hline $\begin{array}{c}\text { Slab track construction } \\
\text { and its group } \\
\text { by classification } \\
\text { (Table 1) }\end{array}$ & \multicolumn{1}{c}{$\begin{array}{c}\text { Country } \\
\text { of origin }\end{array}$} & $\begin{array}{c}\text { Length of construction } \\
\text { used in railway lines, } \\
\text { km }\end{array}$ \\
\hline BÖGL (3) & Germany & 4.391 \\
\hline JSLAB (3) & Japan & 3.044 \\
\hline RHEDA 2OOO (1) & Germany & 2.205 \\
\hline SONNEVILLE-LVT (1) & Switzerland & 1.331 \\
\hline ZÜBLIN (1) & Germany & 606.000 \\
\hline ÖBB-PORR (3) & Austria & 499.000 \\
\hline STEDEF (1) & France & 334.000 \\
\hline INFUNDO-EDILON (5) & The Netherlands & 211.000 \\
\hline IPA (3) & Italy & 100.000 \\
\hline
\end{tabular}




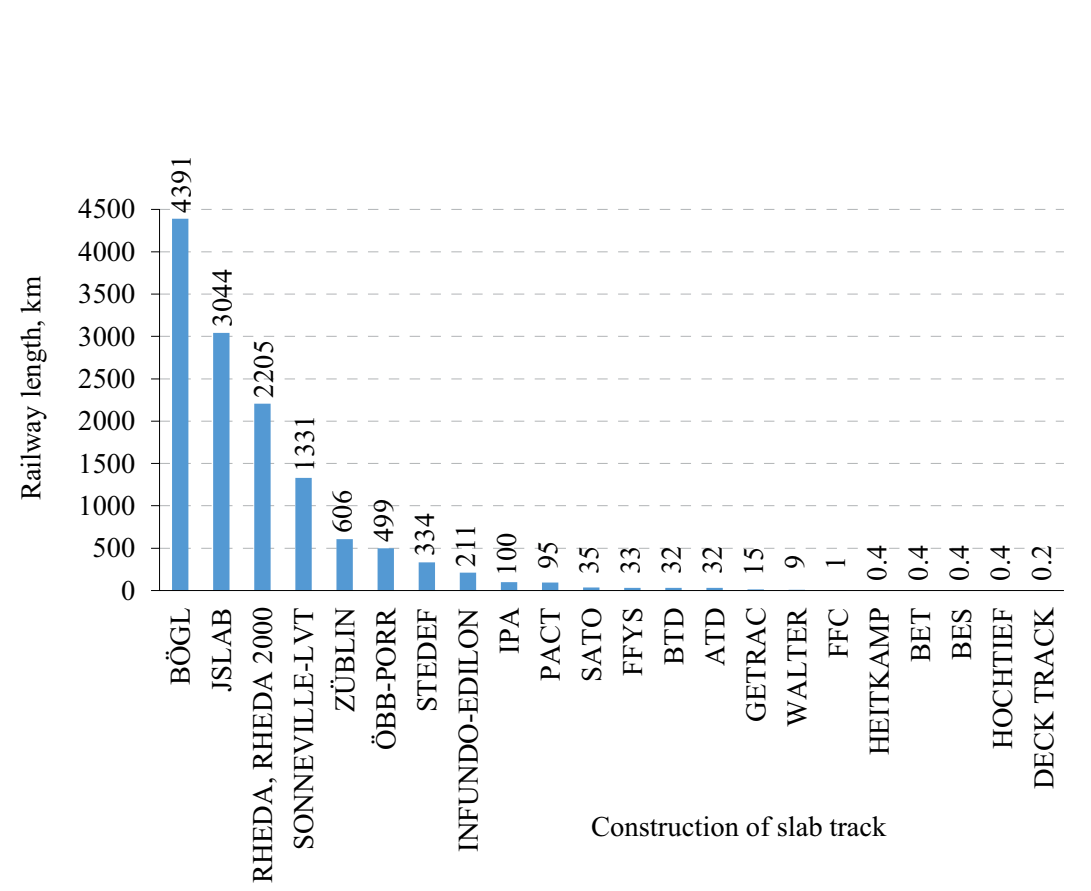

Figure 1. The spread of slab track constructions

- the constructions that are chosen for the comparison and assessment are ascribed for different types of slab track constructions.

In consideration of the presumptions established and data in Table 2, the comparison is made between the slab track constructions that are most widely used in Europe. These are the constructions that, based on their classification, belong to groups 1,3 and 5. The constructions of every group are given in Figures 2-4. They are illustrated with the

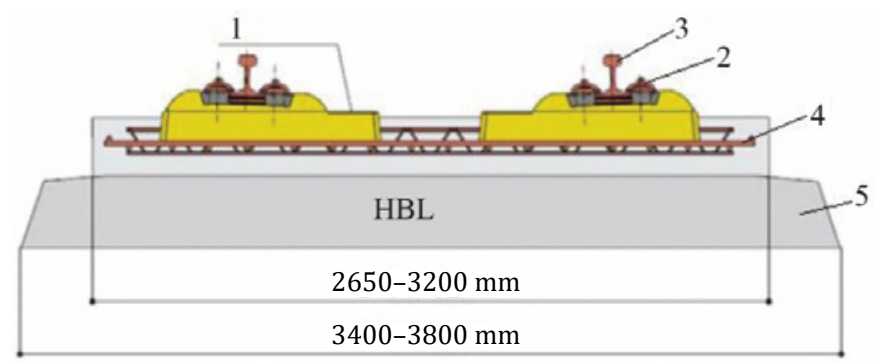

Note: 1 - two-block sleepers B355 (distance between sleepers is $65 \mathrm{~cm}$ ); 2 - couplings Voslloh DFF 300-1; 3 - rail; 4 - longitudinal reinforcement (18 units $d=20 \mathrm{~mm}$ ); 5 - bearing layer bound hydraulically.

Figure 2. RHEDA 2000 slab track construction 

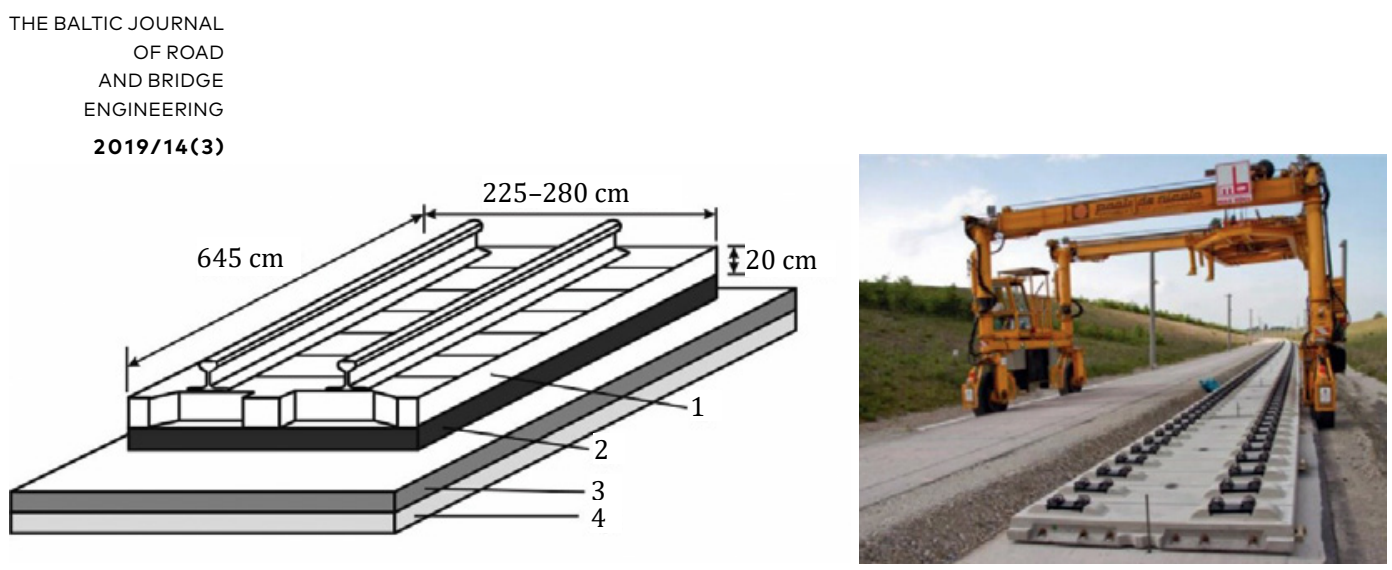

Note: 1 - collectable plates of reinforced concrete; 2 - a layer of asphalt; 3 - layer resistant to cold; 4 - roadbed.

Figure 3. BOGL slab track construction

examples of Rheda 2000 (Germany), Bögl (Germany) and Infundo-Edilon (the Netherlands).

The constructions of collectable plates have:

- advantages:

- high quality of plates manufactured in factories;

- high level of mechanisation;

- disadvantages:

- fast mounting;

- saved labour force upon mounting the construction;

- direct railway regulation and fixation;

- low risk of not achieving a necessary quality;

- easy to repair and reconstruct (easy to replace separate defected parts, if necessary).

Drawbacks of these constructions are as follows:

- significantly higher price than other constructions;

- a high price that sometimes is four times higher than the ballasted track.

The price of the construction rises because the manufactured plates are delivered to the installation location by road transport. Construction elements have a big weight, and the transportation distance from a factory to the installation place most often is very long.

Constructions, where a sleeper or block are mounted in concrete, are widely used due to good performance; long operation experience, compared to other slab track constructions; well-applicable in various non-standard design decisions; the construction is very flexible and provides a possibility to implement project changes and improvements to comply with the requirements of every project. 
Mounted

construction

of a continuous rail

attachment
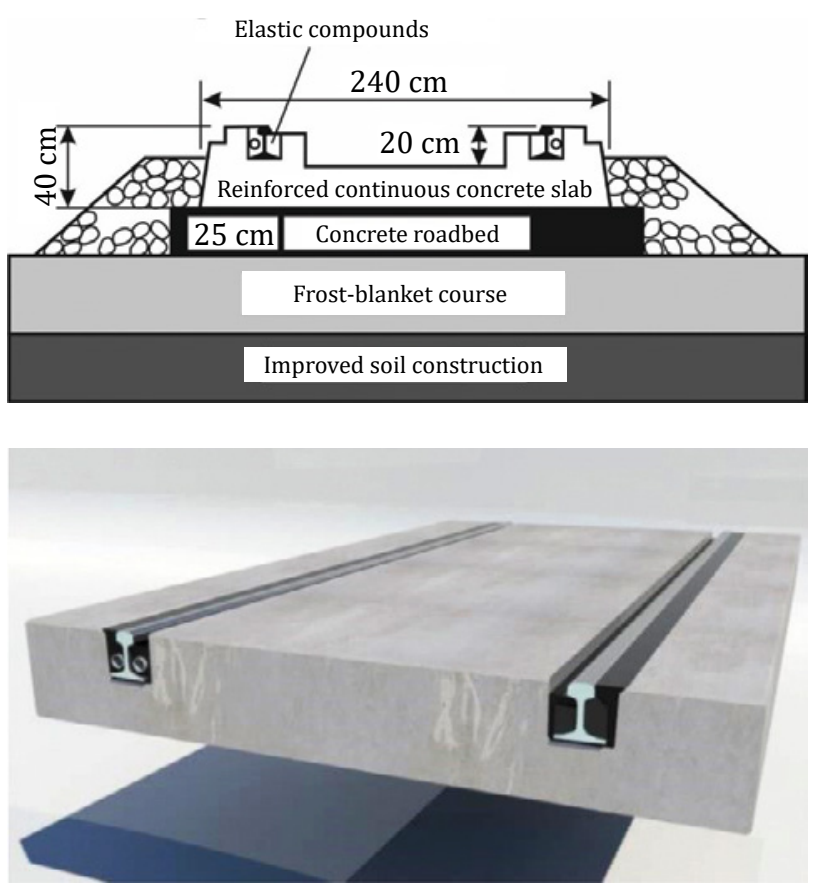

Embedded rail system slab track structure "Edilon"

Figure 4. Infundo-Edilon slab track construction

Mounted constructions have the following advantages:

- wide range of uses - from city transport to high-speed railway lines (on bridges, level crossings);

- effectively mitigated noise level;

- the longer time of railway operation;

- low track maintenance;

- the height of such construction is small; it is reduced, for example, in places where the railway meets a motorway;

- since the railway wear is less, the lighter railway is used;

- less number of construction elements;

- fast construction; a perfect solution for places like level crossings;

- construction best-proven workable on small bridges and level crossings.

Drawbacks:

- special tools necessary for track maintenance, operation difficulties due to the depth of grooves, for example, when welding;

- in case a railway track breaks, non-standard restoration process and tools needed; 
Table 3. Technical and operational indicators of slab track constructions and their assessment

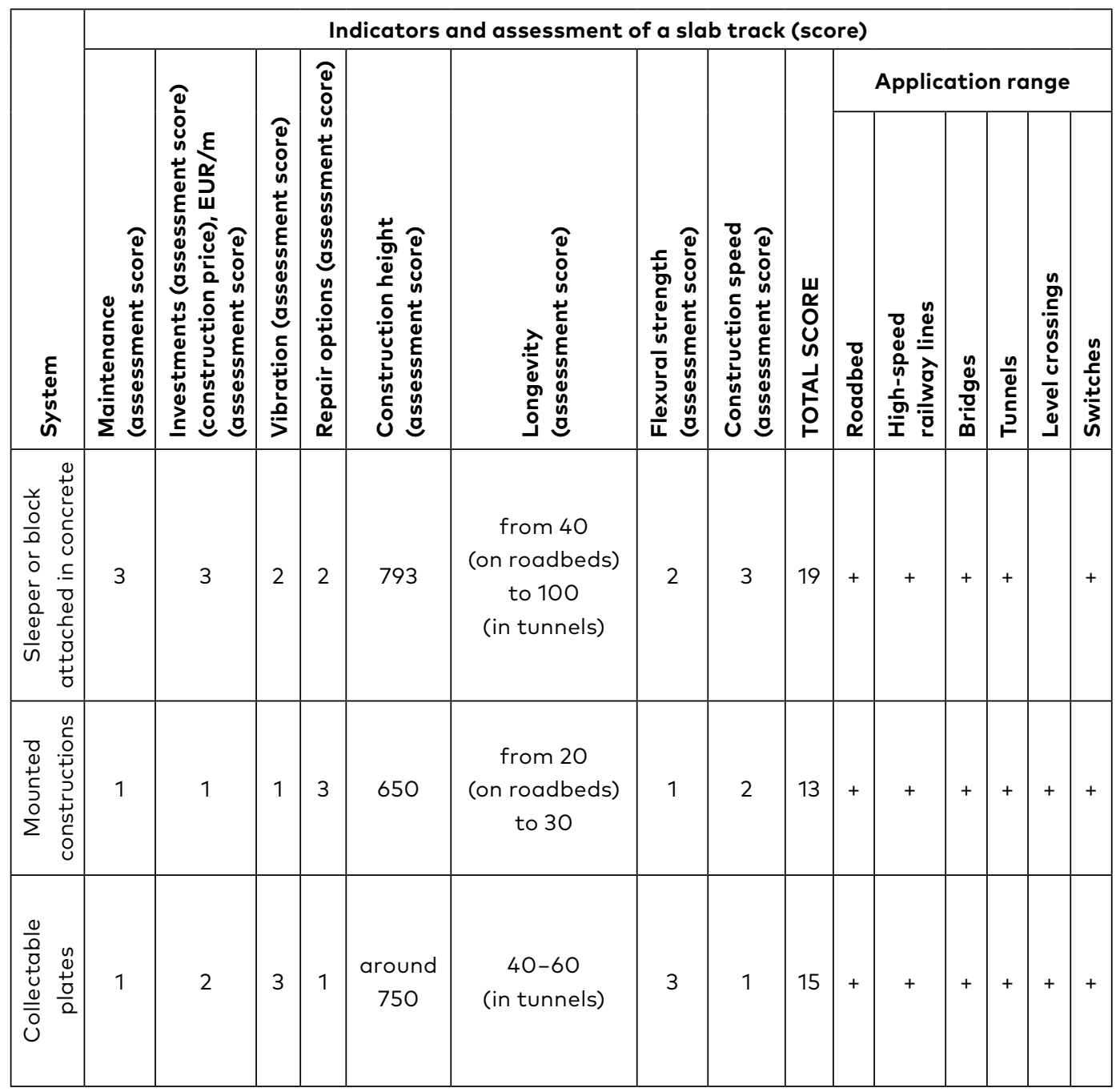

- long intervention period due to resin polymerisation that depends on temperature.

Table 3 provides parameters assigned for the analysis that describe the quality and price of the constructions. All slab track constructions were assessed and ranked (the best construction with the lowest score) using the scoring system. 

and Threats (SWOT) analysis. Lithuanian case

It is essential to evaluate the strengths, weaknesses, opportunities and threats that occur when the construction is being used in the Lithuanian railway networks having performed the comparative assessment of slab track constructions,. The general advantages and disadvantages of the use of slab track are widely known (Gailienè \& Laurinavičius, 2017; Michas, 2012). However, the Strengths, Weaknesses, Opportunities and Threats (SWOT) analysis of the use of slab track in the Lithuanian railway network was performed, taking into account the particular technical, operational conditions and planning of Lithuanian

Table 4. Strengths, Weaknesses, Opportunities and Threats analysis

\begin{tabular}{|c|c|}
\hline Strengths & Weaknesses \\
\hline Clean, dust-free and environmentally & Lack of legal basis \\
\hline friendly & The need for significant investment \\
\hline Access of road rescue vehicles & (high price \\
\hline Maintenance (lower price) & of the construction) \\
\hline \multirow[t]{10}{*}{ Reliable and durable construction } & Corrections are impossible \\
\hline & after implementation \\
\hline & Conditions of the embankments have \\
\hline & to be explored accurately \\
\hline & Protracted repair after \\
\hline & the derailment \\
\hline & During construction and repair \\
\hline & of construction, it is significant \\
\hline & to comply \\
\hline & with technological processes \\
\hline Opportunities & Threats \\
\hline This construction suits the & Financial situation \\
\hline requirements of the high-speed & Lack of experience in the use causes \\
\hline railway lines & overlook of defects and deformations \\
\hline (the compliance to these & Low traffic volume \\
\hline \multicolumn{2}{|l|}{ requirements is significant for the Rail } \\
\hline \multicolumn{2}{|l|}{ Baltica project) } \\
\hline \multicolumn{2}{|l|}{ The LCC of the slab track is lower. } \\
\hline \multicolumn{2}{|l|}{ Growing demand for ecological, safe } \\
\hline and comfortable railway & \\
\hline
\end{tabular}


Table 5. Matrix of Strengths, Weaknesses, Opportunities and Threats analysis

\begin{tabular}{|c|c|c|}
\hline $\begin{array}{c}\text { Strengths - } \\
\text { Weaknesses (SW) } \\
\text { Opportunities - } \\
\text { Threats (OT) }\end{array}$ & Strengths - (S) & Weaknesses - (W) \\
\hline Opportunities - (O) & $\begin{array}{l}\text { OS } \\
\text { Taking advantage } \\
\text { of strength in favour } \\
\text { of an opportunity. } \\
\text { Development of the high- } \\
\text { speed railway network } \\
\text { and Rail Baltica project } \\
\text { provides the opportunity } \\
\text { to construct the high-speed } \\
\text { railway line on the slab } \\
\text { track, which would provide } \\
\text { durable and reliable railway } \\
\text { construction. } \\
\text { The growing requirements } \\
\text { of ecology, security } \\
\text { and comfort mean that } \\
\text { the use of slab track } \\
\text { in the railway stations, } \\
\text { ports, tunnels and level- } \\
\text { crossings should } \\
\text { be discussed. }\end{array}$ & $\begin{array}{l}\text { WO } \\
\text { Overcoming a weakness } \\
\text { by taking advantage } \\
\text { of the opportunity. } \\
\text { The slab track should } \\
\text { not be considered as } \\
\text { the large-investment } \\
\text { railway. } \\
\text { The comparative } \\
\text { analysis of the } \\
\text { constructions should } \\
\text { be LCC-based. }\end{array}$ \\
\hline Threats - (T) & $\begin{array}{l}\text { Taking advantage } \\
\text { of strength to prevent } \\
\text { the threat. } \\
\text { It is essential to perform } \\
\text { the market analysis } \\
\text { and evaluate the influence } \\
\text { of traffic volume revealing } \\
\text { the long-term opportunities } \\
\text { of payback. }\end{array}$ & $\begin{array}{l}\text { Minimisation } \\
\text { of weakness } \\
\text { and avoidance } \\
\text { of threat. } \\
\text { It is essential to have } \\
\text { a clear legal basis } \\
\text { for design, construction, } \\
\text { maintenance and repair } \\
\text { of the slab track. } \\
\text { It would allow not only } \\
\text { to use the slab track } \\
\text { construction but also } \\
\text { to accumulate } \\
\text { the experience. }\end{array}$ \\
\hline
\end{tabular}



(Systra, 2016):

1. Strengths, characteristics of the construction, which give advantages over others (ballasted track);

2. Weaknesses, characteristics that place the construction at a disadvantage relative to others (ballasted track);

3. Opportunities, elements in the environment that the construction is operated to its advantage;

4. Threats, elements in the environment that cause problems for the construction.

The results are shown in Tables 4 and 5 .

The purpose of the SWOT analysis is to analyse and understand how threats are converted into opportunities and weaknesses into strengths. A deeper analysis could be done using the decisions support systems that enable evaluating the pros and cons of a slab track, the satisfaction of preconditions, exclusion criteria. Then there is a need to search for a solution of how to conduct a more precise LCC analysis (Gailienè \& Laurinavičius, 2017).

\section{Conclusions}

1. The abundance of slab track systems that occurred during all of its development stages presents a challenge to railway operators, designers and researchers, about the selection of a right slab track and establishing requirements to it. It is essential to ensure that the track with a ballastless construction complied with the following requirements:

- design speed and axis load of trains must be ensured; track width must be maintained;

- in case the track is in a tunnel, there must be an ability for road transport to go through;

- protection from noise and vibration must be ensured.

The following practice is followed:

- the criteria are established that the slab track systems must comply to be used.

Usually, the following criteria are as follows:

- operation period (60-100 years);

- return of investments (10-25 years);

- increase of initial price compared to a ballasted track (20-50\%).

In certain countries, it is still established how much labour force should be saved on maintenance works (it is established in Japan that 
$30 \%$ of labour force should be saved) and what speed of construction installation is appropriate.

2. After carrying out the analysis of the experience of various countries on the use of slab tracks, it is concluded that entire sections with this construction are most often designed only in high-speed train lines. Usually, in various countries, these constructions are used in certain places - on bridges, roadbeds and in tunnels because they are most beneficial in terms of life cycle cost.

3. A comparative analysis of slab track constructions was carried in this paper. This analysis was used to rank the constructions analysed. It was found that, out of the constructions analysed, the mounted constructions are the best. The second place goes for the collectable constructions, and the last place is for the constructions with a sleeper or block mounted in concrete. Even though the latter is most widely used and there are gathered the most knowledge and experience on them, they concede to other structures because of their high initial investments necessary for construction and long construction period.

4. Slab track is widely known as durable, environmentally friendly, of the low maintenance cost. There are weakness, opportunities and threats, which had to be kept in mind. In this paper, the Strengths, Weaknesses, Opportunities and Threats analysis (Lithuanian case) of the slab track construction was presented. The internal (strengths and weaknesses) and external (opportunities and threats) factors of the slab track construction were analysed. The main conclusion from the matrix of Strengths, Weaknesses, Opportunities and Threats analysis - the slab track has perspectives as environmentally friendly, reliable, durable construction with a low maintenance cost, which is the right decision for high-speed railway line Rail Baltica. However, at the same time, it is essential to provide the comprehensive legal basis setting the requirements of design, construction, maintenance and repair of the slab track because the lack of the legal basis is the source of the main weaknesses. 
Bilow, D. N., \& Randich, G. M. (2000, December). Slab track for the next 100 years. In 2000 Annual Conference Proceedings of American Railway Engineering and Maintenance of Way Association.

Systra (2016). Capacity4rail requirements, concepts and prototype test results (final). Capacity4rail, SCP3-GA-2013-605650.

Dieleman, L., Fumey, M., Robinet, A., Ramondec, P., \& Martin, D. (2008, May). Experimentation of a track section without ballast on the new line of EAST EUROPEAN TGV. In 8th World Congress on Railway Research (pp. 1-16).

Gailienè, I., \& Laurinavičius, A. (2017). The need and benefit of slab track: case of Lithuania. Gradevinar, 387-396. https://doi.org/10.14256/JCE.1776.2016

Esveld, C. (1999). Slab Track: a competetive solution. Delft University of Technology.

Esveld, C. (2003, January). Developments in high-speed track design. In IABSE Symposium Report (Vol. 87, No. 12, pp. 37-45). International Association for Bridge and Structural Engineering.

Fröidh, 0. (2014). Design for new high-speed lines, Journal of Rail Transport Planning \& Management 4(3): 59-69. https://doi.org/10.1016/j.jrtpm.2014.09.002

Gautier, P. E. (2015). Slab track: review of existing systems and optimization potentials including very high speed. Construction and Building Materials, 92, 9-15. https://doi.org/10.1016/j.conbuildmat.2015.03.102

Ižvolt, L., \& Šmalo, M. (2014). Historical development and applications of unconventional structure of railway superstructure of the railway infrastructure of the Slovak Republic. Civil and Environmental Engineering, 10(1), 79-94. https://doi.org/10.2478/cee-2014-0010

Yokoyama, A. (2010). Infrastructure for high speed lines in Japan. International Practisum on Implementing High-Speed Rail in the United States.

Marx, L., \& Mosmann, D. (2013). Work procedures for permanent way maintenance. 7 th revised and extended edition. DB Manual

Profillidis, V. (2016). Railway management and engineering. Routledge.

Michas, G. (2012). Slab Track systems for high-speed railways. Master degree project. Royal Institut of Technology, Stockholm, Sweden. 95 p.

Mörscher, J. (1999, September). Slab track roadbeds in Germany-implementation and experience. In AREMA Annual Conferences Track \& Structures.

Pichler, D., \& Fenske, J. (2013). Ballastless track systems experiences gained in Austria and Germany. In Proc. of AREMA Annual Conference.

Tayabji, S. (2000). Concrete slab track for freight and high speed service applications. A survey of practice. 